Ocula ${ }^{15}$

Commemorating Charles S. Peirce (1839-1914):

interpretive semiotics and mass media

A cura di Giampaolo Proni e Salvatore Zingale

Novembre 2014 I www.ocula.it - DOI: 10.12977/ocula29

\title{
Peircean Semiotics and Transmedia Dynamics \\ Communicational Potentiality of the Model of Semiosis
}

Geane Carvalho Alzamora

Federal University of Minas Gerais, Belo Horizonte, Brazil

geanealzamora@ufmg.br

Renira Rampazzo Gambarato

National Research University Higher School of Economics, Moscow, Russia

rgambarato@hse.ru

\begin{abstract}
In this article, we discuss the pragmatic relationship between semiosis and communication in order to characterize transmedia dynamics as a pragmatic offshoot of semiosis in media, a perspective that accounts for the incompleteness of the interpretant in its meditated actions. The theoretical approach is based on the communication perspective of the sign developed by Charles Sanders Peirce and his contemporary commentators, such as Parmentier (1985), Colapietro (1995, 2004), Santaella (1992, 1995, 2003, 2004), and Bergman (2000, 2003, 2007). In addition, transmedia dynamics are explored according to Jenkins (2001, 2006, 2013), Göran (2012), and Jansson (2013). We discuss the notion of media as sign mediation and transmedia dynamics as an improvement of semiosis, based on the pragmatic approach to the latter. Transmedia narratives refer to integrated media experiences that unfold across a variety of platforms, attracting audience engagement and offering new and pertinent content. Moreover, the productive incompleteness of the interpretant is taken as a conceptual parameter for understanding the way in which media consumption regulates habits and delineates the transmedia narrative in the sign process of network associations. In conclusion, we stress how the semiotic operation of representation, associating new signs and collateral experience, without losing the narrative reference (semiotic operation of determination), emerged in transmedia environments.
\end{abstract}

Keywords

Peirce, Model of Semiosis, Transmedia Storytelling, Communicational Process, Media

\section{Summary}

1. Introduction

2. Communicational Process of the Model of Semiosis

3. Media and the Model of Semiosis

4. Conclusion

References 


\section{Ocula $a^{15}$}

Commemorating Charles S. Peirce (1839-1914): interpretive semiotics and mass media

Geane Carvalho Alzamora, Renira Rampazzo Gambarato, Peircean Semiotics and Transmedia Dynamics

\section{Introduction}

The thoughts of Charles Sanders Peirce (1839-1914) have been recurrently solicited in order to understand aspects related to communication theory. The communication perspective of the sign tends to be addressed within the framework of its speculative grammar, a strand of logic or semiotics ${ }^{1}$, which studies the physiology of signs (CP 2.83) ${ }^{2}$, such as the classification of sign types. However, Bergman (2000, 2007) considered that communication could also be addressed in the context of rhetoric.

We focus our discussion on the pragmatic relationship between semiosis and communication in order to characterize transmedia dynamics as a pragmatic offshoot of semiosis in media. This perspective accounts for the pragmatic incompleteness of the interpretant in its mediated actions.

Peircean late pragmatism is an abductive matter (CP 5.197) and can be considered a regulatory principle of logic (Santaella, 1992). This perspective permeates the normative sciences, in particular the three divisions of logic, although the scope of our discussion is more restricted. According to Colapietro (1995), Peirce's general theory of signs, and his distinctive conception of pragmatism, cannot be separated from one another.

On the one hand, pragmatism is itself the semiotic doctrine; on the other, Peirce attempts to render clear (er) our conception or semiosis (or sign-action) and to classify the types of signs are, at bottom, the work of a pragmatism or, better, a pragmaticism. (Colapietro, 1995, p. 24).

The pragmatic perspective of semiosis translates into a pragmatic approach to communication, since communication and cognition arise from the transformative action of the sign. The communicative function highlighted by a cognitive assumption is evidenced in the identification between sign and medium that Peirce argued in his more mature writings (MS 339), "All my notions are very narrow. Instead of Signs, ought I not to say Medium?” (Parmentier, 1985, p. 23).

Meaning, within the Peircean approach, refers to the mediation function of the sign. The Peircean notion of "medium", since it subscribes to his notion of thirdness, is therefore far more comprehensive than the idea of vehicle or channel, as it is commonly treated in other theories of mass communication. "A sign is plainly a species of medium of communication, and medium of communication is a species of medium, and a medium is a species of third" (MS 283). It is this perspective that underlies our approach.

1 For over 40 years, Peirce dedicated himself to building his classification of sciences, which articulated successive triadic relations, as specified in his three phenomenological categories: Firstness, secondness, and thirdness. Semiotics is the third among the normative sciences, right after aesthetics and ethics. They are all derived from philosophy, a science of secondness (see Kent, 1987; Santaella, 1992).

2 Following the scholarly tradition, Peirce's work is referred to as CP (followed by volume and paragraph number for quotes from The Collected Papers of Charles $S$. Peirce, Peirce 1931-1935, 1958), EP (followed by volume and page number for quotes from The Essential Peirce, Peirce 1998), and MS (followed by reference number of the manuscript from The Charles S. Peirce Papers, Peirce 1963-1966, 1979). 


\section{Ocula $a^{15}$}

Commemorating Charles S. Peirce (1839-1914): interpretive semiotics and mass media

Geane Carvalho Alzamora, Renira Rampazzo Gambarato, Peircean Semiotics and Transmedia Dynamics

\section{Communicational Process of the Model of Semiosis}

Sign mediation articulates semiosis, which intertwines sign (representamen), object, and interpretant in a web of endless relations, along with semiotic operations of determination and representation. The semiotic operation of representation is mediated by determination, and the latter by representation. The interpretant may thus represent the object, which determines it through mediated action of the sign and becomes itself, determinant of the subsequent triad (MS 318).

According to Peirce's later writings, the semiotic operation of mediation circumscribes the semiotic operation of representation. Representation is therefore an aspect of mediation: Semiotic operation delineates the notions of sign and semiosis in Peirce's mature works. "In this semiotic model it is the sign relation itself rather than one element taken alone that reveals a triadic, synthetic, and mediational quality" (Parmentier, 1985, p. 38).

With regard to semiosis, the sign unfolds continuously in triadic relations established between the sign itself, its object, and its interpretant ${ }^{3}$. Broader notions that outline the semiosis relate the object to reality and the interpretant to the truth, meaning that these notions are pragmatically updatable; always partial and incomplete within the semiosis dynamics.

The object determines the sign in order to produce a real effect, the interpretant. The way that the object reveals itself partially on the sign is the immediate object, being the dynamic object of the external determination to the sign (reality). As the object always escapes the sign representation to some extent, other signs join the triad by collateral experience (CP 3.14) to form the interpretant that represents the object, in partial and incomplete sign mediation.

The representative action of the interpretant, which involves several triadic subdivisions, is highly relevant in understanding the pragmatic logic of semiosis, which directs the flow of signs toward an ideal of truth that would represent an ideal of reality, if it was possible to reach such a stage of semiosis. "The interpretant is nothing but another representation to which the torch of truth is handed along" (CP 1.339).

Interpretant is a term that Peirce characterized as being the effect and meaning of the sign, be it current, potential, or future (Bergman, 2003). The diversity of interpretants, which goes from mere interpretative capability to an ideal of understanding that relates to the notion of truth, was crafted by Peirce in divisions that specify the term in functional and differentiated stages. One of the best-known classifications refers to the immediate interpretant inscribed in the sign, the dynamic interpretant (concrete effect) and the final interpretant (ideal effect), respectively, in the domain of firstness, secondness, and thirdness.

Peircean scholars differ on the location of the semiosis regarding the divisions related to emotional, energetic, and logical interpretants (see Santaella,

3 These relationships, which will not be explored here as they lack pertinence, result in 10 divisions, which reveal 64 kinds of signs that could lead to 59,049 logical possibilities of sign varieties (see Santaella, 1995). 


\section{Ocula $a^{15}$}

Commemorating Charles S. Peirce (1839-1914): interpretive semiotics and mass media

Geane Carvalho Alzamora, Renira Rampazzo Gambarato, Peircean Semiotics and Transmedia Dynamics

2004). Peirce identified the logical interpretant within the sphere of habits. "Therefore, there remains only habit, as the essence of the logical interpretant" (MS 318) and this, according to Peirce, participates vigorously in communicative processes (see Johansen, 1993). According to Santaella (2004), it is the identification of the logical interpretant with habit, in the light of Peircean late pragmatism, which makes the semiosis no longer an infinite abstract process, but places it in pragmatic connection with human action.

For Colapietro (1995), habits played, in communication processes observed through the lens of Peircean theory, a similar role to codes in communication processes reviewed by authors within the Saussurean tradition. Habits regulate conduct, just as codes regulate messages. The logical interpretant and its related habits lead the way to a dialogical association of ideas, resulting in communication.

In a division of interpretants specifically related to the dialogic communication process, Peirce stated that a communicative intention comes from the mind of the issuer (intentional interpretant) to determination from the mind of the interpreter (effectual interpretant), which should result in a "fusion" of the minds of the issuer and the interpreter (communicational interpretant or cominterpretant) through some form of agreement that presupposes a common experience (common ground).

Peirce did not explicitly mention how this division of interpretants is related to other divisions of interpretants in the model of semiosis, but Johansen (1993) considered there to be a clear relationship between intentional interpretant and immediate interpretant; effectual interpretant and dynamical interpretant; and cominterpretant and final interpretant. This proposal finds resonance in the work of Deledalle, who considered that "the interpretant is formally the sign. Just as the representamen is the sign of the sender, the interpretant is the sign of the receiver" (1997, p. 58). In Bergman's view (2007), the common ground, although the prerequisite for communication in the Peircean framework, does not amount to a demand for identity of experiences; true communicational exchange and development requires experiential divergences.

Although this division of interpretant is the only one that is explicitly related to communication, it is not discussed here as an offshoot of semiosis, but as a way of understanding semiosis in its communicational aspect. Being the interpretant, the sign mediator between a previous and subsequent triadic sign, we will clarify how its productive incompleteness is a communicative question within transmedia narratives.

\subsection{The Productive Incompleteness of Interpretants}

In counterpoint to the dualistic structure of thought, there is dialectical logic, originating from Hegelianism, in which the apprehension of reality is in permanent transformation. Opposite sides/thoughts complement each other, forming the whole. From this relativization of opposites a third, which is none of the others, is generated. In this context the Peircean (logic) semiotics is observed, which features triadic structures that enable the generation of new 


\section{Ocula $a^{15}$}

Commemorating Charles S. Peirce (1839-1914): interpretive semiotics and mass media

Geane Carvalho Alzamora, Renira Rampazzo Gambarato, Peircean Semiotics and Transmedia Dynamics

interpretants ad infinitum. His speculative grammar is dedicated to investigating the nature of representation, and therefore addresses Peirce's main triad, as previously discussed: Sign/object/interpretant.

The interpretant is the effect generated by the translation of signs, while the interpreter is the one who allows this translation. Although the interpretant is normally described as the understanding reached throughout semiosis, it could be more properly thought of as the translation, the development of the sign. "The idea is that the interpretant provides a translation of the sign, allowing us a more complex understanding of the sign's object" (Atkin, 2013).

The interpretant is the third element of the triad; it is the mediator of the first (sign) and the second (object), it is the one that generates meaning. For Peirce, interpretants are generated at varying levels or degrees. The bestknown division of interpretants was presented in 1906, and further developed in 1909, and maintains the triadic pattern: 1) immediate interpretant - it "consists in the Quality of the impression that a sign is fit to produce" (CP 8.315); 2) dynamical interpretant - it "is whatever interpretation any mind actually makes of a sign" (CP 8.315); and 3) final interpretant - it "is that which would finally be decided to be the true interpretation if consideration of the matter were carried so far that an ultimate opinion were reached" (EP 2:496). Moreover:

In regard to the Interpretant we have [...] to distinguish, in the first place, the Immediate Interpretant, which is the interpretant as it is revealed in the right understanding of the Sign itself, and is ordinarily called the meaning of the sign; while in the second place, we have to take note of the Dynamical Interpretant which is the actual effect which the Sign, as a Sign, really determines. Finally there is what I provisionally term the Final Interpretant, which refers to the manner in which the Sign tends to represent itself to be related to its Object. (CP 4.536)

However, also in 1906, Peirce elaborated another trichotomy subdividing interpretants into: 1) Emotional - "the first proper significant effect of a sign is a feeling produced by it" (CP 5.475); 2) energetic - "if a sign produces any further proper significant effect, it will do so through the mediation of the emotional interpretant, and such further effect will always involve an effort. I call it the energetic interpretant" (CP 5.475); and 3) logic - "the essential effect upon the interpreter, brought about by the semiosis of the sign" (CP 5.480). In addition to the discussions around either the semantic uniformity or distinctness of the two trichotomies (see Lalor, 1997; Short, 1981; Lizska, 1990), our focus is also on understanding the recursive logic of generating interpretants and, above all, its productive incompleteness.

The interpretant generated by the sign is also another sign. As such, the interpretant will necessarily generate another sign that acts as its interpretant, and so forth ad infinitum. Peirce's conception of semiosis involves abstractness, and it "is partly purchased by abstracting from the interpreter of signs, whereas what counts as an object of any sign does so only in reference to the purpose of some agent and, thus, in connection with the role of some interpreter" (Colapietro, 2004, p. 22). 


\section{Ocula $a^{15}$}

Commemorating Charles S. Peirce (1839-1914): interpretive semiotics and mass media

Geane Carvalho Alzamora, Renira Rampazzo Gambarato, Peircean Semiotics and Transmedia Dynamics

The incompleteness of semiosis itself, and consequently of interpretants generated in this open-ended process, may correspond to the richness of the variability of interpretations that a sign/object/interpretant relationship can evoke. "The meaning of any sign for anybody consists in that he reacts to the sign" (CP 8.315). The dynamical interpretant is particularly prepared to produce variability for involving both emotions and actions:

[...] texts can further be characterized as having different interpretants according to their effects on their interpreters [...]. Texts that arouse emotions or provoke immediate action, such as larmoyant novels, literature of agitation, and particularly advertising, have a dynamical interpretant. (Nöth, 1995, p. 47)

The dynamical interpretant is experienced in each act of interpretation. In Peirce's words, "the volitional element of interpretation is the Dynamical Interpretant" (EP 2:496). What then would be the value of this variability of interpretation allowed by the dynamical interpretant? First, semiotics refers to signification, representation, reference and meaning, and Peirce emphasized the importance of interpretation to signification, which differentiates his theory of signs. Second, in the realm of creative industries, the richness of communicative possibilities lies in a sense of freedom, the absence of conditioning, and an elimination of the obvious. The ultimate logic interpretant, an interpretant that itself has no further interpretant (CP 5.491), does not contribute to diversity. Indeed, "Peirce's dynamical interpretant designates the creative potentialities of signs" (Ponzio, 1990, p. 327).

Our knowledge encapsulates our repertoire in the form of memory, and we consequently build combinations and relationships that generate new interpretants connected with signs. Thus, the interpretant becomes dynamic and constantly changes, allowing technological, aesthetic, artistic, and scientific progress, etc.

\section{Media and the Model of Semiosis}

The sign chain unfolds incompletely, but it is continuously enhanced by the mediated action of the interpretant. The idea of mediation in Peirce assumes transmission, update, and association of information. This perspective is particularly interesting in understanding contemporary communicational processes deeply marked by networked connections. The dynamics of association, which articulates other signs in a semiosis by collateral experience, is a dynamic network that updates, in some respects, what the object transmits to the sign by means of the action of interpretant in its various divisions.

Before discussing the particularities of transmediality, we position the intermedia network dynamics in the context of semiosis, which is also a model of communication. Santaella and Nöth (2004) argued that the triadic sign is a maximum abstraction of three key elements of every communicative process, respectively: Object (logical place of the emitter), sign (logical place of utterance), and interpretant (logical place of the interpreter). Based on this perspective, we understand sign mediation as the logical place of networked 


\section{Ocula $a^{15}$}

Commemorating Charles S. Peirce (1839-1914): interpretive semiotics and mass media

Geane Carvalho Alzamora, Renira Rampazzo Gambarato, Peircean Semiotics and Transmedia Dynamics

connections and we thus position the sign in a logical place of languages, vehicles, and messages.

According to Deledalle, semiosis creates habits, and these habits constitute the messages and their exchanges. "In Peircean terms, media are vehicles of sinsigns 4 " (1997, p. 570). In a similar approach, Walther stated that the sinsign, a noticeable and particular replica of legisign, is the part of the sign that can be transmitted in semiosis, once the qualisign is inherent to the sign and the legisign is general and abstract. "Emitter and receiver, or object and interpretant, are related by the medium, which depends on time and space" (1997, p. 86).

The sign mediation puts the sign exchanges in a spatio-temporal relationship within each media environment, as in its intermedia connections. If the medium, as thirdness, regulates the semiosis and, as secondness, interchanges information in concrete situations, we can understand intermedia connections as sinsigns that occur on the basis of habits that govern the uses of media and their connections. Jost (2011) proposed that generational habits are tied to different media. Thus, the habits that form the intermedia semiosis regulate the consumption habits in each media environment that crosses the network dynamics. They contribute to more broadly changing the regulatory domains of each media environment in network dynamics.

A narrative that is to be expanded into the transmedia realm should present both an intermedia dimension and a multimedia configuration. An intermedia network is structured around compatibility and permeability (Weinz, 2008). In this context, intermedia refer to forms of production and circulation of information that occur on the crossing and complementarity of media environments without the displacement of media references. In addition to the media complementarity, transmedia narratives would also assume the displacement of aesthetic, social, and symbolic aspects, tending to merge genres and formats (Alzamora \& Tárcia, 2012).

The sign, as a vehicle of information (CP 5.231), can be understood as a pragmatic process of continuous improvement of the information that emerges from sign mediation through the representative action of interpretant. From this perspective, transmissible processes of information occur within the domain of the semiotic operation of determination, while network-sharing processes occur within the domain of the semiotic operation of representation. Semiosis does not exist without determination and representation, although these operations can appear in different domains in the process of sign mediation (Alzamora, 2007).

On the basis of the idea of transmission, the mass media propitiates the semiotic operation of determination, which atrophies the communicative process in some respects. Cherry commented that, in a strict Peircean sense, these are not communication systems at all, because no mutual sharing takes place (1980, p. 259). Social media, based on the idea of sharing, operate under the domain of semiotic representation. The semiosis integrates the dynam-

4 In relation to itself, the sign (representamen) can be a qualisign, sinsign, or legisign, respectively, positioned in the firstness, secondness, and thirdness domains. 


\section{Ocula $a^{15}$}

Commemorating Charles S. Peirce (1839-1914): interpretive semiotics and mass media

Geane Carvalho Alzamora, Renira Rampazzo Gambarato, Peircean Semiotics and Transmedia Dynamics

ics of transmission and the dynamics of sharing in a convergent mediation of networked connections, merging some sign characteristics of mass and social media.

The pragmatic improvement of intermedia dynamic favors both the mass media, which tend to become more dialogic when joined in convergent dynamics, as well as social media, which tend to share visibility of broadcasting media by means of information-sharing within networks. However, this process does not occur without friction, since the convergence processes include divergence (Jenkins, 2001), in addition to the fact that the formation of common ground requires experiential divergences (Bergman, 2007).

\subsection{Media, Semiosis and Transmediality}

Media convergence requires the concomitant use of a variety of media environments, governed by dissonant and communicational, although complementary, logics. Convergence is not a technologic matter, but a sign question in our approach. According to Jenkins (2006), convergence represents a cultural transformation to the extent that consumers are encouraged to seek out new information and make connections among dispersed media content. He highlighted the role of participatory culture in this scenario. Cultural transformation based on participatory culture is here understood in association with semiosis.

The question becomes even clearer when approached by the prism of circulation or movement of media content in network connections. Jenkins, Ford, and Green (2013) designed this process of spreadable media that check an emerging hybrid model of circulation, where the mix of top-down and bottom-up forces the determination of how material is shared across, and among, cultures in far more participatory ways.

The hybrid model of circulation, based on convergent dynamics, interferes in the sign configuration in each media environment through its regulatory action (thirdness) expressed qualitatively (firstness) in the media contiguity (secondness). Convergent dynamics is thus a type of pragmatic improvement of the logic of transmission that drives the processes of communication in mass media. In this context, transmedia narrative, a specificity of convergence (Alzamora \& Tárcia, 2012), could denote an improved unfolding of narratives that characterizes each particular medium.

"Signs are growing" (Santaella, 2003, p. 185). In the noosphere, the realm of interaction between nature and society, or more specifically in Lotman's semiosphere, the signs are expanding without interruption, and the new technologies are partially determinant in this exponential growth. Certainly, it reflects on media communication in general and on transmediatic production in particular. Transmedia narratives refer to, "at least, integrated media experiences that occur amongst a variety of platforms. A transmedia narrative tells altogether one big pervasive story, attracting audience engagement. It is not about offering the same content in different media platforms, but it is the worldbuilding experience, unfolding content and generating the possibilities for the story to evolve with new and pertinent content" (Gambarato, 2013b, 


\section{Ocula $a^{15}$}

Commemorating Charles S. Peirce (1839-1914): interpretive semiotics and mass media

Geane Carvalho Alzamora, Renira Rampazzo Gambarato, Peircean Semiotics and Transmedia Dynamics

p. 82). Jansson considered transmedia narratives as "increasingly inter-connected and open-ended circulation of media content between various platforms, where the subjects previously known as 'the audience' are increasingly involved in the production of flows" (2013, p 287). Göran (2012) discussed the influential consequences of the digitalization of media production, distribution, and reception, shaping user creativity and industry opportunities. In the age of prosumers, the variability of creation, and therefore interpretation of signs, is far more widespread than ever before.

The sign determines the interpretant, "by focusing our understanding on certain features of the signifying relation between sign and object" (Atkin, 2013). In the transmediatic space 5 both media industries and media users are not just able, but compelled, to collaborate and co-create, which includes the generation of signs/interpretants according to the interests and goals of the parties involved.

In order to promote the richness of the productive incompleteness of interpretants, the creation of signs that are distant from their objects is preferred to the detriment of the signs that are (evidently) closer to their objects. The larger distance between sign and object will contribute to promoting the absence of conditioning and elimination of the obvious. The question that arises is how to do it though? A possible answer is by means of association of ideas by similarity instead of by contiguity. Contiguity corresponds to an elementary reasoning, a familiar knowledge (CP 7.218) in which ideas are associated because they are close; they are suggested by daily experience, which impoverishes their originality and their creative production. In contrast, similarity is a more elaborate form of reasoning; it is a conscious process in which ideas are approached by some equality, some analogy.

Similarity emphasizes the creative aspect because it is not the resemblance between ideas or facts that allows the association, but it is the association, as control of the reasoning, that produces the resemblance. Similarity can occur by resemblance of quality, juxtaposition or mediation. The first one happens when identity of qualitative characteristics exists among parts of the sign; when the parts, in their physical and sensitive materiality, present qualities. Secondly, there is the resemblance of juxtaposition. In this case, in spite of elements being different, the proximity among them gives rise to resemblances. Ideogram is an example of this sort of association. The third way, characterized by mediation, happens when a third term produced in the mind that can unite two states of consciousness, for instance, verbal and visual metaphors. (Gambarato, 2013a)

The association of ideas is a dynamic process of generation of interpretants. The action of the sign, or the process of semiosis, should result in interpretants that are neither ultimate nor static, otherwise the conservatism,

5 "Transmedia space appears as a notion that integrates meta- and intercommunicative levels, presuming the interpretation of the same message as the sequence of proto- and metatexts described in different discourses and fixed in different signs systems and media" (Saldre \& Torop 2012, p. 41). 


\section{Ocula $a^{15}$}

Commemorating Charles S. Peirce (1839-1914): interpretive semiotics and mass media

Geane Carvalho Alzamora, Renira Rampazzo Gambarato, Peircean Semiotics and Transmedia Dynamics

the stagnation of the creative process will be favored. The design of transmedia outlets would have the purpose of associating signs and generating new interpretants. Certainly each user/prosumer would produce different interpretants related to the same object according to his/her informational level and within his/her own repertoire. This variability of signification could be a desirable characteristic of transmedia productions. The generation of dynamical interpretants that are constantly being updated can transform the overall experience offered within transmedia dynamics.

\section{Conclusion}

In conclusion, we stress social participation in the context of transmedia dynamics collateral experience, that is, how the semiotic operation of representation combines new signs and collateral experience without losing the narrative reference (semiotic operation of determination) emerging in transmedia environments. Thus, the habits that regulate consumption in media environments within transmedia narratives also manage the production and sharing of information in transmedia dynamics. In this sense, it is because of the productive incompleteness of the interpretant that transmedia narratives unfold in an enhanced, and always incomplete, mode in the process of semiosis. What motivates social participation is referred to as the emotional interpretant, what guides the effort of participation is connected to the energetic interpretant and what leads to coherence within the collective production pertains to the logic interpretant. Narrative coherence is provided by the communicative intention related to the immediate interpretant in consonance with the effective communication expressed through the interpretant. The common interpretation is the result of a regulatory instance that coexists as an ideal (final interpretant), as suggested by Johansen (1993). However, as this ideal is pragmatic, the effective occurrences are also divergent (Bergman, 2007), which may arise in order to motivate the communicational activity in subsequent triadic relations within transmedia narratives.

Furthermore the appropriation of concepts of Peircean semiotics, such as semiosis, sign, object, and interpretant, contributes to the understanding of the communicational potentiality involved in contemporary transmedia productions and can favor additional creative development within transmedia spaces. 


\section{Ocula $\mathbf{a}^{15}$}

Commemorating Charles S. Peirce (1839-1914): interpretive semiotics and mass media

Geane Carvalho Alzamora, Renira Rampazzo Gambarato, Peircean Semiotics and Transmedia Dynamics

\section{References}

Alzamora, Geane

2007 "Da semiose midiática à semiose hipermidiática: jornalismos emergentes”, in Melo, J. and Paiva, R. (editors), Ícones da sociedade midiática - da aldeia de McLuhan ao planeta de Bill Gates, Rio de Janeiro, Mauad X, pp. 157-175.

Alzamora, Geane; Tárcia, Lorena

2012 Convergence and Transmedia - Semantic Galaxies and Emerging Narratives in Journalism, "Brazilian Journalism Research", 8(1), pp. 22-34.

Atkin, Albert

2013 "Peirce's Theory of Signs", in Zalta, E. (editor), The Stanford Encyclopedia of Philosophy, Retrieved from http://plato.stanford.edu/archives/sum2013/entries/ peirce-semiotics.

Bergman, Mats

2000 Reflection on the Role of the Communicative Sign in Semiotic, "Transactions of the Charles S. Peirce Society: A Quarterly Journal in American Philosophy”, XXXVI(3), pp. 225-254. Retrieved from http://www.jstor.org/ discover/10.2307/ 27795018?uid=3737664\&uid=2134\&uid=2480592033\&uid=2\&uid=70\&uid=3\&uid=2480592023\&uid=60\&purchasetype=both\&acces sType $=$ none\&sid $=21103860743193 \&$ showMyJstorPss $=$ false\&seq $=1 \&$ showAc cess $=$ false.

Bergman, Mats

2003 Peirce's Derivation of the Interpretant, "Semiotica”, 144, pp. 1-17.

2007 Common Ground and Shared Purposes: On Some Pragmatic Ingredients of Communication, “Cognitio", 8(1), pp. 23-43.

Cherry, Colin

1980 "The Communication Explosion", in Foster, M. and Brandes, S. (editors), Symbols as Sense, New York, Academic Press, pp.249-267.

Colapietro, Vincent

1995 "Immediacy, Opposition and Mediation: Peirce on Irreducible Aspects of the Communicative Process", in Langsdorf, L. And Smith, A. (editors), Recovering Pragmatism's Voice - The Classical Tradition, Rorty and the Philosophy of Communication, Albany, State University of New York Press, pp.23-48.

Colapietro, Vincent

2004 The Routes of Significance: Reflections on Peirce's Theory of Interpretants, "Cognitio", 5(1), pp. 11-27.

1997 “Media between Balnibarbi and Plato's Cave”, in Nöth, W. (editor), Semiotics of the Media - State of the Art, Projects, and Perspective, Berlin/New York, Mouton de Gruyter, pp.49-60.

Gambarato, Renira

2013a Peircean Semiotics in the Context of Design Praxis: Abduction and Perception in Dialogue, "Sign Systems Studies", 41(4), pp. 424-432.

2013b Transmedia Project Design: Theoretical and Analytical Considerations, "Baltic Screen Media Review”, 1, pp. 80-100. 
Geane Carvalho Alzamora, Renira Rampazzo Gambarato, Peircean Semiotics and Transmedia Dynamics

Göran, Bolin

2012 "Audience Activity as a Co-production of Crossmedia Content", in Ibrus, I. And Scolari, C. (editors), Crossmedia Innovations - Texts, Markets, Institutions, Frankfurt, Peter Lang, pp.147-159.

Jansson, André

2013 Mediatization and Social Space: Reconstructing Mediatization for the Transmedia Age, "Communication Theory", 23, pp. 279-296.

2001 Convergence? I diverge, "Technology Review”, Retrieved from http://phase1. nccr-trade.org/images/stories/jenkins_convergence_optional.pdf

Jenkins, Henry

2006 Convergence Culture - Where Old and New Media Collide, New York, New York University Press.

Jenkins, Henry; Ford, Sam; Green, Joshua

2013 Spreadable Media, New York, New York University Press.

Johansen, Jorgen

1993 Let Sleeping Signs Lie: On Signs, Objects, and Communication, "Semiotica", 97-3/4, pp. 271-295.

Jost, François

2011 Novos comportamentos para antigas mídias ou antigos comportamentos para novas mídias?, "Matrizes”, 4(2), pp. 93-109.

Kent, Beverley

1987 Logic and the Classification of the Sciences, Kingston/Montreal, McGillQueen's University Press.

Lalor, Brendan

1997 The Classification of Peirce’s Interpretants, "Semiotica", 114-1/2, pp. 31-40.

Liszka, James

1990 Peirce's Interpretant, “Transactions of the Charles Sanders Peirce Society”, 26, pp. 17-62.

Nöth, Winfried

1995 Handbook of Semiotics, Bloomington/Indianapolis, Indiana University Press.

Parmentier, Richard

1985 "Sign's Place in media res: Peirce's Concept of Semiotic Mediation”, in Merz, E. and Parmentier, R. (ed.), Semiotic Mediation, Orlando, Academic Press, pp.23-48.

Peirce, Charles S.

1931-1935, 1958 Collected Papers of Charles Sanders Peirce, vols. 1-6, Hartshorne, C. and Weiss, P. (editors), vols. 7-8, Burks, A. (editor), Cambridge, Harvard University Press.

1963-1966, 1979 The Charles S. Peirce Papers, 30 reels, 3rd microfilm edition, Cambridge, The Houghton Library, Harvard University, Microreproduction Service.

1998 The Essential Peirce. Selected Philosophical Writings, vol. 2, 1893-1913. Peirce Edition Project (editor), Bloomington, Indiana University Press. 


\section{Ocula $a^{15}$}

Commemorating Charles S. Peirce (1839-1914): interpretive semiotics and mass media

Geane Carvalho Alzamora, Renira Rampazzo Gambarato, Peircean Semiotics and Transmedia Dynamics

Ponzio, Augusto

1990 Man as a Sign: Essays on the Philosophy of Language, Berlin, Mouton de Gruyter.

Saldre, Maarja; Torop, Peeter

2012 "Transmedia Space”, in Ibrus, I. and Scolari, C. (editors), Crossmedia Innovations - Texts, Markets, Institutions, Frankfurt, Peter Lang, pp.25-44.

Santaella, Lúcia

1992 A assinatura das coisas - Peirce e a literatura, São Paulo, Imago.

1995 A teoria geral dos signos - semiose e autogeração, São Paulo, Ática.

2003 Cultura das mídias, São Paulo, Experimento.

2004 The Role of Habit Changing in Peirce's Evolutionist Pragmatism, "Cognitio", 5(1), pp. 75-83.

Santaella, Lúcia; Nöth, Winfried

2004 Semiótica e comunicação, São Paulo, Hacker Editores.

Short, Thomas

1981 Semeiosis and Intentionality, "Transactions of the Charles Sanders Peirce Society", 17, pp. 197-223.

Walther, Elisabeth

1997 "The Sign as Medium, the Medium Relation as the Foundation of the Sign", in Nöth, Winfried (editor), Semiotics of the Media. State of the Art, Projects, and Perspectives. Berlin/New York, Mouton de Gruyter, pp.79-97.

Weinz, Karin

2008 "As formas intermidiáticas em textos digitais", in Santaella, L. and Nöth W. (editors), Palavra e imagem nas mídias - um estudo intercultural, Belém, Editora Universitária UFPA, pp.249-270.

Geane Carvalho Alzamora is Associate Professor in the Social Communication Department at the Federal University of Minas Gerais, Brazil. At the moment, she is post-doctorate fellow at Pompeu Fabra University, Spain and she holds a PhD in Communication and Semiotics from Pontifical Catholic University of São Paulo, Brazil; a MA in Communication and Semiotics also from Pontifical Catholic University of São Paulo and a BA in Journalism from Pontifical Catholic University of Minas Gerais, Brazil. Dr. Alzamora's research related to the topic of this paper is supported by CNPq and Fapemig.

Renira Rampazzo Gambarato is Assistant Professor in the Faculty of Media Communications at the National Research University Higher School of Economics, in Moscow, Russia. Her Post-doctorate in Film Studies is from Concordia University, Canada and she holds a PhD in Communication and Semiotics from Pontifical Catholic University of São Paulo, Brazil; a MA in Communication and Semiotics also from Pontifical Catholic University of São Paulo and a BA in Industrial Design from São Paulo State University, Brazil. 